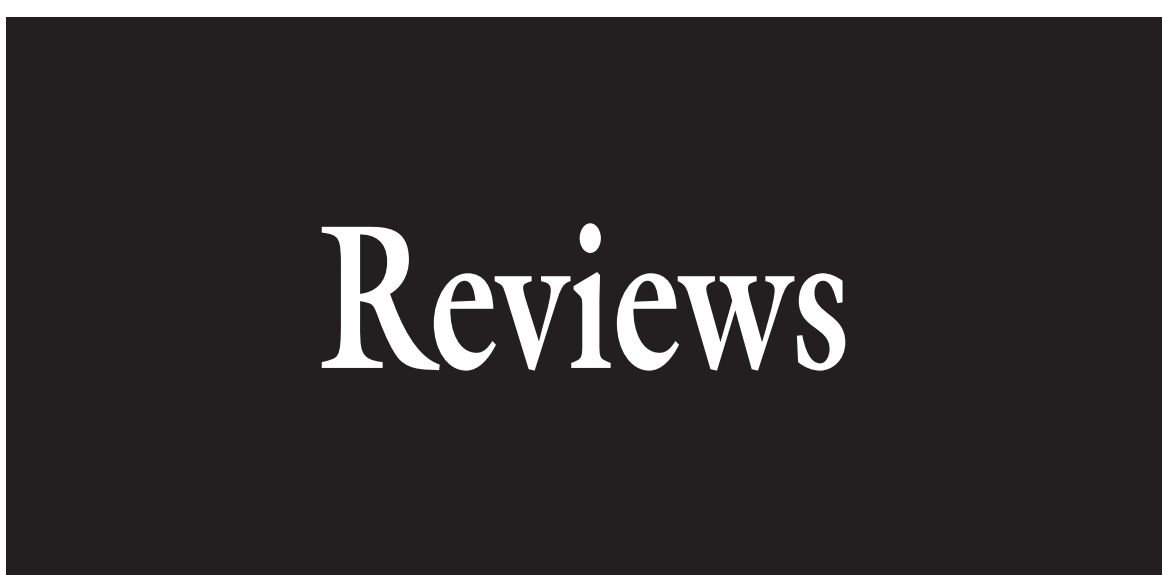

\section{Intercropping for Field Production of Peppers}

\author{
Brian A. Kahn ${ }^{1}$
}

Additional Index words. Capsicum annuum, competition, land equivalent ratio, vegetables

SUMMARY. This review summarizes studies involving intercropping for field production of peppers [Capsicum spp. (typically Capsicum annumm)]. Intercropping is particularly important in developing countries and where arable land is limited. Fruit crops, vegetables, forages, and other crops representing over 12 botanical families have been intercropped with peppers. System recommendations may be affected by whether one is attempting to grow another species as an intercrop in a pepper field or whether peppers are being used as an intercrop in a different primary crop. Other factors such as the timing of the intercrop planting, climatic conditions, and local economics all contribute to the potential success or failure of intercropping with peppers. Although broad recommendations cannot be made, the reviewed studies offer several examples of successful combinations of peppers with other crops.

$\mathrm{I}$ ntercropping - the growing of two or more crops simultaneously on the same land-makes efficient use of limited arable land. However, it can complicate chemical pest control as a result of residues and label restrictions, and it is a labor-intensive practice. Traditionally, intercropping has been practiced most widely in developing countries (Francis and Decoteau, 1993). However, the advantages of intercropping, particularly the potential for increasing sustainability (Coolman and Hoyt, 1993), have stimulated interest in the practice in the United States and other developed countries.

Professor, Department of Horticulture and Landscape Architecture, 358 Agricultural Hall, Oklahoma State University, Stillwater, OK 74078-6027

Approved for publication by the Director, Oklahoma Agricultural Experiment Station. This research was supported in part under project $\mathrm{H}-2026$.

The information given in this publication is for educational purposes only. Mention of a trademark, proprietary product, or vendor does not constitute a guarantee or warranty of the product nor does it imply approval or disapproval to the exclusion of other products or vendors that may also be suitable.

${ }^{1}$ Corresponding author. E-mail: brian.kahn@okstate.edu. lent ratio" (LER) was developed by Mead and Willey (1980). The LER is the most common index for measuring the advantages of using intercropping systems on the combined yield of both crops (Francis and Decoteau, 1993). The LER is calculated as the yield of a crop in an intercrop system relative to the yield of that crop in a monocrop system (that is, intercrop yield/monocrop yield).

Many different species have been intercropped with peppers. The reviewed literature has been organized by botanical family of the primary intercropped species.

\section{Onion family (Alliaceae)}

Prabhakar and Shukla (1990) compared cropping systems over three
The concept of a "land equiva- successive seasons (monsoon, winter, and summer) in India. In the winter, a pepper-onion (Allium cepa) intercrop increased returns by $59 \%$ over sole-crop pepper but decreased returns by $36 \%$ over sole-crop onion. The intercropping system was able to accommodate only $30 \%$ of the normal population of onion.

Mallangouda et al. (1995) intercropped pepper with onion, garlic (Allium sativum), or coriander (Coriandrum sativum) during the rainy season in India. The pepper-garlic intercrop receiving recommended fertilization rates produced the highest net return.

Kabura et al. (2008) compared various pepper-onion intercrop spacings and sole plantings of each crop in Nigeria. The sole plantings generally outyielded the intercrops, but some combinations gave overall LER values greater than 1. Recommended spacings for intercrops varied depending on the primary crop in the system. If one was adding onion plants to a pepper field, a pepper spacing of $60 \times 30$ $\mathrm{cm}$ with onion planted at $15 \times 40 \mathrm{~cm}$ minimized interplant competition and gave an average overall LER of 1.18. If onion was the primary crop and a pepper crop was being added, an onion spacing of $15 \times 20 \mathrm{~cm}$ with pepper planted at $60 \times 45 \mathrm{~cm}$ reduced shading by the pepper plants and gave an average overall LER of 1.16.

\section{Mustard family (Brassicaceae)}

Guldan et al. (1997b) interseeded forage brassicas [kale (Brassica oleracea Acephala group), rape (Brassica napus), and turnip (Brassica rapa Rapifera group)] into standing crops of chile pepper (C. annuum) at two different times per season in New Mexico. This was an example of relay intercropping; that is, planting a second crop after an initial crop has reached maturity but before harvest is completed on the initial crop (Coolman and Hoyt, 1993). Intercrops reduced pepper yield compared with a solecropped control in only 1 of 3 years. Brassica yields were satisfactory and generally were higher with early August

\begin{tabular}{llll}
\hline $\begin{array}{l}\text { Units } \\
\begin{array}{l}\text { To convert U.S. to SI, } \\
\text { multiply by }\end{array}\end{array}$ & U.S. unit & SI unit & $\begin{array}{l}\text { To convert SI to U.S., } \\
\text { multiply by }\end{array}$ \\
\hline 0.3048 & $\mathrm{ft}$ & $\mathrm{m}$ & 3.2808 \\
2.54 & inch(es) & $\mathrm{cm}$ & 0.3937
\end{tabular}


seeding than with mid-August seeding into the pepper crop. They concluded that interseeding forage turnip into chile pepper in early August could help support animals that were allowed to graze the pepper fields after the pepper plants had died (late fall) on mixed crop-livestock farms.

Hooks and Johnson (2001) intercropped broccoli (B. oleracea Italica group) with chile pepper in Hawaii. Broccoli plant biomass in intercropped plots was equivalent to, or greater than, that in monocropped plots, but contamination of broccoli heads by several lepidopterous pests was greatest in the broccoli-pepper system. Unfortunately, pepper yields were not reported.

Kaur and Khurana (2008) intercropped cabbage (B. oleracea Capitata group) with tomato (Solanum lycopersicum), pepper, muskmelon (Cucumis melo), and cucumber (Cucumis sativus). The LER was highest (5.4) and net returns were best with the cabbagetomato intercrop, followed by the cabbage-pepper intercrop, which had a LER of 3.7.

\section{Bromeliad family (Bromeliaceae)}

Uriza-Ávila et al. (2005) studied various intercrops for pineapple ( $A n a-$ nas comosus) production in Mexico. Pineapple yield and quality were not reduced by jalapeño pepper intercrops established during the first $80 \mathrm{~d}$ of the pineapple growth cycle. The pineapple plants protected the intercropped pepper plants against adverse effects from heavy rains and strong winds. As a result, yields from intercropped pepper were $30 \%$ to $50 \%$ higher than yields from monocropped pepper.

\section{Spurge family (Euphorbiaceae)}

Olasantan et al. (2007) evaluated the effects of cassava (Manihot esculenta) on the growth and yields of pepper compared with sole cropping. Cassava tuber yield was unaffected by intercropping with pepper, and total gross returns were greater with intercropping than with growing either cassava or pepper in monoculture. Intercropping pepper between rows of cassava was successful if a suitable cassava cultivar (early and relatively short) was chosen.

\section{Legume family (Fabaceae)}

Hulugalle and Willatt (1987) planted pepper and soybean (Glycine $\max$ ) in alternate rows. They found that leaf water potential of pepper plants intercropped with soybean was generally greater than that of monocropped pepper plants. The authors speculated that this was the result of a windbreak effect from the soybean rows. Pepper plant populations differed between the monocrop and intercrop treatments, so pepper yields could not be compared.

Chen et al. (1989) conducted a study of alley cropping various vegetables, including pepper, in hedgerows of white leadtree (Leucaena leucocephala) in Nigeria. With appropriate fertilization, there were no yield differences between crops grown with alley cropping compared with sole-cropped controls.

Several experiments were conducted involving interseeding legumes into chile pepper in New Mexico. Pepper yield was unaffected by intersowing with hairy vetch (Vicia villosa), barrel medic (Medicago truncatula), or black lentil (Lens culinaris) (Guldan et al., 1996). Hairy vetch intercropped with pepper and managed as a winter annual increased the yield of a following crop of forage sorghum (Sorghum bicolor) compared with an unfertilized control (Guldan et al., 1997a). However, interseeding snap pea (Pisum sativum) into stands of chile pepper was not economically advantageous compared with monocropped pepper (Guldan et al., 1998).

Emeasor and Ezueh (1997) found that intercropping pepper intrarow with cowpea (Vigna unguiculata) reduced flower thrips (Megalurothrips sjostedti) and cowpea aphids (Aphis craccivora) on cowpea and improved cowpea yield compared with solecropped cowpea. However, pepper yields were not reported.

De Costa and Perera (1998) studied intercrop combinations of bean (Phaseolus vulgaris) and pepper in Sri Lanka. Intercrop bean yields were lower than sole crop bean yields. However, intercrop pepper yields were greater than sole crop pepper yields, and the LER of the intercrops was greater than 1 .

Anitha et al. (2001) intercropped pepper with bean and amaranth (Amaranthus spp.) in India. Pepper intercropped with bean yielded more than pepper intercropped with amaranth or monocropped pepper.

\section{Geranium family (Geraniaceae)}

Ram and Kumar (1998) studied six potential intercrop combinations for sweet-scented geranium (Pelargonium graveolens) production in northern India. The tested geranium-pepper intercrop gave an average LER of 1.36, but this was inferior to the best combination, a geranium-wild marigold (Tagetes minuta) intercrop that gave an average LER of 1.53 .

\section{Mallow family (Malvaceae)}

Lawal and Rahman (2007) reported that irrigation and fertilization improved yields and economic returns of an okra (Abelmoschus esculentus) and pepper intercrop. Monocrops were not included in this study.

\section{Grass family (Poaceae)}

Ramamurthy et al. (1993) concluded that intercropping pepper with fingermillet (Eleusine coracana) reduced pepper yields by $88 \%$ compared with a pepper monocrop. They speculated that shading of the pepper plants by the fingermillet was a major contributor to the pepper yield reduction.

\section{Rose family (Rosaceae)}

Duval (2005) found no yield differences between strawberry plants (Fragaria $\times$ ananassa) relay intercropped with various vegetables, including bell pepper, and those not intercropped. It was possible to plant bell pepper up to $31 \mathrm{~d}$ before the end of the strawberry fruit harvest without having a detrimental effect on strawberry fruit yield.

\section{Citrus family (Rutaceae)}

Aiyelaagbe (2001) intercropped juvenile sweet orange (Citrus $\times$ sinensis) trees planted on $7 \times 7-\mathrm{m}$ spacing with various crops in Nigeria. Intercropping orange with a pepper-amaranth combination gave the highest net revenue for the total system and did not impair orange fruit yield.

\section{Nightshade family (Solanaceae)}

Hussein and Abdul Samad (1993) compared monocropped pepper with pepper intercropped with maize (Zea mays) or with eggplant (Solanum melongena). Maize acted as a barrier crop for aphids (Aphis gossypii) and reduced virus infection on pepper in the first part of the cropping season. Eggplant 
acted as a trap crop for aphids and reduced virus infection on pepper for a longer period than did maize. As a result, yields of pepper plants intercropped with eggplant were the highest in the trial.

\section{Ginger family (Zingiberaceae)}

Sharma and Bajaj (1998) used bell pepper intercrops as a means to control nematodes infesting ginger (Zingiber officinale) in India. Intercropping at a $1: 1$ ratio gave the highest ginger yield and eliminated two key nematode species [root lesion nematode (Pratylenchus penetrans) and root-knot nematode (Meloidogyne incognita)] in the tested area.

\section{Conclusions}

Factors such as whether peppers are the primary crop in the system (Kabura et al., 2008; Olasantan et al., 2007; Sharma and Bajaj, 1998), the timing of the intercrop planting (Duval, 2005; Guldan et al., 1997b), climatic conditions (Prabhakar and Shukla, 1990), pest pressure (Emeasor and Ezueh, 1997; Hooks and Johnson, 2001; Sharma and Bajaj, 1998), and local economics (Guldan et al., 1998; Kaur and Khurana, 2008; Ram and Kumar, 1998) all contribute to the potential success or failure of intercropping with peppers. Positive results are most likely to occur when plant-to-plant competition can be minimized, for example when peppers are used as intercrops in young orchards (Aiyelaagbe, 2001) or in hedgerow crops (Chen et al., 1989). Relay intercropping can also increase the likelihood of success (Duval, 2005; Guldan et al., 1997b). Intercropping may succeed if cultural factors like fertilization and irrigation are adjusted (Chen et al., 1989; Lawal and Rahman, 2007; Mallangouda et al., 1995), but some crop combinations may simply be too competitive to produce economic benefits (Ramamurthy et al., 1993). Although broad recommendations cannot be made, the reviewed studies offer several examples of successful combinations of peppers with other crops.

\section{Literature cited}

Aiyelaagbe, I.O.O. 2001. Productivity of an intercropped sweet orange orchard in southwestern Nigeria. Biol. Agr. Hort. 18:317-325.
Anitha, S., V.L. Geethakumari, and G. Raghavan Filial. 2001. Effect of intercrops on nutrient uptake and productivity of chilli-based cropping system. J. Trop. Agr. 39:60-61.

Chen, Y.S., B.T. Kang, and F.E. Caveness. 1989. Alley cropping vegetable crops with Leucaena in southern Nigeria. HortScience 24:839-840.

Coolman, R.M. and G.D. Hoyt. 1993. Increasing sustainability by intercropping. HortTechnology 3:309-312.

De Costa, W.A.J.M. and M.K.K.W. Perera. 1998. Effects of bean population and row arrangement on the productivity of chilli/ dwarf bean (Capsicum annumm/Phaseolus vulgaris L.) intercropping in Sri Lanka. J. Agron. Crop Sci. 180:53-58.

Duval, J.R. 2005. Relay-intercropping does not reduce strawberry yield in an annual-hill production system. HortTechnology 15:907-908.

Emeasor, K.C. and M.I. Ezueh. 1997. The influence of companion crops in the control of insect pests of cowpea in intercropping systems. Trop. Agr. 74:285-289.

Francis, R. and D.R. Decoteau. 1993. Developing an effective southernpea and sweet corn intercrop system. HortTechnology 3:178-184.

Guldan, S.J., C.A. Martin, J. Cueto-Wong, and R.L. Steiner. 1996. Interseeding legumes into chile: Legume productivity and effect on chile yield. HortScience 31:1126-1128.

Guldan, S.J., C.A. Martin, W.C. Lindemann, J. Cueto-Wong, and R.L. Steiner. 1997a. Interseeding legumes into chile: Legume benefits to a following crop of forage sorghum. HortTechnology 7:146149.

Guldan, S.J., C.A. Martin, and R.L. Steiner. 1997b. Interseeding forage brassicas into chile: Forage productivity and effect on chile yield. J. Sustain. Agr. 11: 41-49.

Guldan, S.J., C.A. Martin, and C.L. Falk. 1998. Interseeding snap pea into stands of chile pepper reduces yield of pea more than that of chile. HortScience 33:660 662 .

Hooks, C.R.R. and M.W. Johnson. 2001. Broccoli growth parameters and level of head infestations in simple and mixed plantings: Impact of increased flora diversification. Ann. Appl. Biol. 138:269280 .

Hulugalle, N.R. and S.T. Willatt. 1987. Seasonal variation in the water uptake and leaf water potential of intercropped and monocropped chillies. Exp. Agr. 23:273282.
Hussein, M.Y. and N. Abdul Samad. 1993. Intercropping chilli with maize or brinjal to suppress populations of Aphis gossypii Glov., and transmission of chilli viruses. Intl. J. Pest Manage. 39:216-222.

Kabura, B.H., B. Musa, and P.E. Odo. 2008. Evaluation of the yield components and yield of onion (Allium cepa L.)pepper (Capsicum annumm L.) intercrop in the Sudan savanna. J. Agron. 7:88-92.

Kaur, H. and D.S. Khurana. 2008. Production potential and economics of vegetables intercropped with cabbage. Environ. Ecol. 26:1872-1874.

Lawal, A.B. and S.A. Rahman. 2007. Effect of irrigation, fertiliser and manure on yield and economic return of okra/ pepper intercrops. Trop. Sci. 47:45-48.

Mallangouda, B., G.S. Sulikeri, B.G. Murthy, and N.C. Prathibha. 1995. Productivity and economics of chilli (Capsicum annuиm)-based intercropping systems under different fertility levels. Indian J. Agron. 40:502-504.

Mead, R. and R.W. Willey. 1980. The concept of a 'land equivalent ratio' and advantages in yields from intercropping. Exp. Agr. 16:217-228.

Olasantan, F.O., A.W. Salau, and E.E. Onuh. 2007. Influence of cassava (Manihot esculenta) intercrop on growth and fruit yields of pepper (Capsicum spp.) in south-western Nigeria. Exp. Agr. 43:7995.

Prabhakar, B.S. and V. Shukla. 1990. Crop land use efficiency in sequential intercropping systems with vegetables. Indian J. Hort. 47:427-430.

Ram, M. and S. Kumar. 1998. Intercropping medicinal, spice and oil seed crops with geranium (Pelargonium graveolens) for improving productivity in assured input system of a subtropical environment. J. Medicinal Aromatic Plant Sci. 20: 1060-1066.

Ramamurthy, V., G.V. Havanagi, and H.V. Nanjappa. 1993. Intercropping of chilli (Capsicum annumm) and fingermillet (Eleusine coracana) under dryland condition. Indian J. Agron. 38:283-285.

Sharma, G.C. and B.K. Bajaj. 1998. Effect of inter-cropping bell-pepper with ginger on plant parasitic nematode populations and crop yields. Ann. Appl. Biol. 133: 199-205.

Uriza-Ávila, D.E., A. Rebolledo-Martínez, and L. Rebolledo-Martínez. 2005. Short cycle crops intercropped with pineapple: An option to increase productivity. Acta Hort. 666:287-294. 